\title{
Berkebun di Rumah pada Masa Pandemi dengan Memanfaatkan Sampah Rumah Tangga
}

\author{
Gardening at Home during the Pandemic by Using Household Waste
}

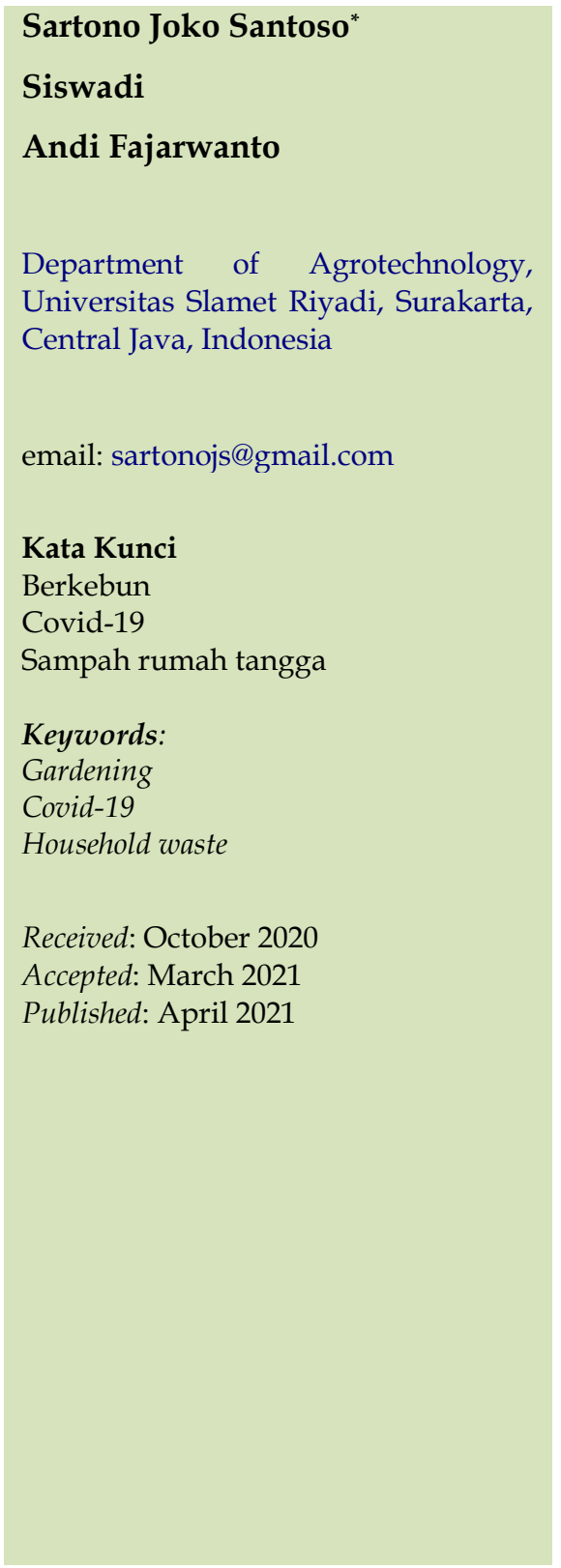

\begin{abstract}
Abstrak
Pangan merupakan kebutuhan dasar bagi manusia yang harus dipenuhi setiap saat sebagai kebutuhan dasar, pangan mempunyai arti dan peran yang sangat penting bagi kehidupan suatu bangsa. Permasalahan yang dihadapi pada masa pandemic covid 19 ini telah memaksa setiap orang berdiam diri dan bekerja dari rumah sehingga setiap orang berupaya untuk memanfaatkan waktu luang tersebut dengan kegiatan yang produktif. Salah satu kegiatan tersebut yaitu berkebun di rumah dengan memanfaatkan sampah rumah tangga. Untuk mewujudkan hal tersebut maka mulai bulan april sampai bulan September 2020, tim pengabdian masyarakat melakukan penyuluhan dan pelatihan serta praktek kepada kelompok tani ngubo amuktiwo kelurahan Kestalan Kecamatan Banjasari Kota Surakarta Jawa Tengah. Hasi dari pelaksanaan program menunjukan bahwa pandemic covid 19 memaksa setiap warga khususnya kelompok mitra beraktifitas di rumah yang mengakibatkan banyak waktu luang yang tersedia, maka berkebun di rumah dengan memanfaatkan sampah rumah tangga sebagai media tanam merupakan solusi paling tepat dikarenakan lingkungan jadi bersih dan sehat serta hasil panen tanamannya bisa memenuhi kebutuhan dapur yang berimbas pada berkurangnya pengeluaran. Disamping itu jika program ini dilaksanakan secara nasional maka tujuan ketahanan pangan masyarakat akan bisa tercapai.
\end{abstract}

\begin{abstract}
Food is a basic need for humans that must be fulfilled as a basic need; food has an essential meaning and role in a nation's life. The problems faced during the Covid 19 pandemic have forced everyone to keep quiet and work from home so that everyone tries to take advantage of this free time with productive activities. One of these activities is gardening at home using household waste. To make this happen, from April to September 2020, the community service team conducted counseling and training and practices for the Amuktiwo Ngubo farmer group, Kestalan sub-district, Banjasari District, Surakarta City, Central Java. The results of the program show that the Covid 19 pandemic forces every citizen, especially partner groups, to do activities at home, which results in a lot of free time available, so gardening at home by using household waste as a planting medium is the most appropriate solution because the environment is clean and healthy. The crop yields can meet the needs of the kitchen, which results in reduced expenses. Also, if this program is implemented nationally, the goal of community food security will be achieved.
\end{abstract}

(C) 2021 Sartono Joko Santosa, Siswadi Siswadi, Andi Fajarwanto. Published by Institute for Research and Community Services Universitas Muhammadiyah Palangkaraya. This is Open Access article under the CC-BYSA License (http://creativecommons.org/licenses/by-sa/4.0/). DOI: https:// doi.org/10.33084/ pengabdianmu.v6i3.1772

\section{PENDAHULUAN}

Ketahanan pangan menjadi salah satu isu hangat yang tengah menjadi perhatian dunia di tengah pandemi
Covid-19. Negara-negara di dunia, termasuk Indonesia berupaya menghindari krisis pangan seperti yang telah diperingatkan Food and Agriculture Organization (FAO) (Suryani, 2020). Pangan merupakan kebutuhan dasar 
bagi manusia yang harus dipenuhi setiap saat. Sebagai kebutuhan dasar, pangan mempunyai arti dan peran yang sangat penting bagi kehidupan suatu bangsa. Ketersediaan pangan yang lebih kecil dibandingkan kebutuhannya dapat menciptakan ketidakstabilan ekonomi. Berbagai gejolak sosial dan politik dapat juga terjadi jika ketahanan pangan terganggu (Lantarsih et al., 2011). Saat ini, krisis pangan menghantui Indonesia sebagai dampak pandemi Covid-19. Banyak upaya dilakukan berbagai pihak guna mengantisipasinya. Masyarakat mulai melakukan penghematan dan menanam bahan pangan lokal, gerakan beli hasil tanaman pangan petani lokal juga digencarkan (Wulandani \& Anggraini, 2020).

Masa pandemi Covid-19 memaksa setiap orang untuk tinggal di rumah demi memutus mata rantai penyebaran virus. Kondisi ini tidak serta merta membuat kita menjadi tidak produktif. Beragam aktivitas bisa dilakukan, khususnya yang bias menopang kebutuhan pangan rumah tangga. Salah satu yang bisa dilakukan adalah berkebun sayuran organik di pekarangan rumah (Syahputra, 2020).

Berkebun di rumah memang memiliki manfaat besar, baik untuk memenuhi akses pangan hingga untuk mengurangi stres saat harus tinggal lebih lama di rumah. Selama masa pandemi Covid-19, semakin banyak orang khususnya yang tinggal di perkotaan menghabiskan waktunya menanam atau berkebun di rumah. Walau pada umumnya halaman rumah tidaklah seberapa luas, namun bukan jadi penghalang untuk tetap menanam (Ashari et al., 2012).

Pada ruang yang sempit sekalipun, beragam tanaman masih bisa ditanam dengan sistem polybag atau hidroponik dengan media tanam dari sampah rumah tangga yang diproses menjadi pupuk organik. Hidroponik adalah salah satu cara bercocok tanam yang inovatif untuk diterapkan masyarakat di masa sekarang.
Proses penerapan hidroponik dilakukan dengan sangat sederhana dan tidak memerlukan banyak tempat. Selain itu, banyak keuntungan yang bisa didapatkan melalui bercocok tanam hidroponik. Di masa pandemi Covid-19 ini, banyak masyarakat yang bekerja dari rumah sehingga banyak waktu luang yang dimiliki (Permadi et al., 2020).

Hampir setiap hari, rumah kita menghasilkan sampah, baik dari dapur maupun halaman rumah. Alangkah bijaknya jika kita mampu memanfaatkan sampah tersebut sehingga tidak terbuang percuma dan berakibat buruk bagi lingkungan. Kebun organik di halaman rumah dapat menjadi sarana pemanfaatan yang tepat melalui aplikasi langsung maupun pengolahan tertentu. (Cahya, 2014). Dwiyanto (2011) menyatakan bahwa untuk mencapai kondisi masyarakat yang hidup sehat dan sejahtera di masa yang akan datang, akan sangat diperlukan adanya lingkungan permukiman yang sehat. Dari aspek persampahan, maka kata sehat akan berarti sebagai kondisi yang akan dapat dicapai bila sampah dapat dikelola secara baik sehingga bersih dari lingkungan permukiman dimana manusia beraktifitas di dalamnya (Rosnawati et al., 2017).

Potret keadaan diatas juga terjadi pada kelompok tani "Ngubo Amuktiwo" di Kelurahan Kestalan Kecamatan Banjarsari Surakarta. Jawa Tengah yang merupakan mirta pada kegiatan ini. Kelompok mitra merupakan kelompok bapak - bapak yang mempunyai kepedulian tentang pemanfaatan pekarangan rumah tangga yang terbatas berkonsep "Kawasan Rumah Pangan Lestari" (KRPL). Lingkungan mitra merupakan daerah perkotaan yang padat penduduknya sehingga masalah lingkungan khususnya sampah dan pemanfatan pekarangan menjadi perhatian khusus bagi mereka. Mitra mempunyai potensi untuk dikembangkan kegiatannya mengingat sampai saat ini semangat para anggotanya demikian besar terbukti mereka seringkali 
mengikuti kegiatan-kegiatan yang dilaksanakan Pemerintah Kota Surakarta sebagai contoh pada bulan Februari tahun 2019 mereka ikut musrenbang di Dinas Pertanian, Peternakan dan Perikanan Kota Surakarta. Yang juga di hadiri kalangan perguruan tinggi yang antara lain Fakultas Pertanian Universitas Slamet Riyadi Surakarta.

Mengacu pada situasi pandemi yang saat ini sedang melanda kita dan analisis situasi mitra diatas maka telah disepakati solusi untuk menyelesaikannya berdasar pada permasalahan yang ada pada mitra, yaitu:

1. Masih rendahnya tingkat kesadaran masyarakat tentang pentingnya kebersihan dan kesehatan lingkungan. Untuk mengatasi masalah ini dilakukan penyuluhan dan pengetahuan tentang pentingya kebersihan dan kesehatan lingkungan'

2. Kurangnya pengetahuan mitra terhadap cara - cara pengelolaan sampah dan pemanfaatan pekarangan yang sempit. Untuk Mengatasi masalah ini perlu tambahan pengetahuan dan ketrampilan dalam mengelola sampah maupun mengelola pekarangan yang sempit melalui penyuluhan dan simulasi.

3. Tidak disadarinya bahwa sampah dan pekarangan yang sempit bisa mendatangkan uang. Untuk masalah ini sampah organik diproses menjadi pupuk organik yang laku dijual. Sedangkan untuk pekarangan sempit dapat di budidayakan tanaman secara hidroponik dengan media dari pupuk tersebut.

\section{METODOLOGI}

Untuk mencapai target luaran yang telah direncanakan, program ini dilakukan melalui tahapan sebagai berikut:

\section{Pemaparan Materi}

Metode yang digunakan dengan memakai teknik ceramah dengan media pembelajaran secara daring melalui WA grup. Adapun materi yang diberikan yaitu:

a. Pentingnya menjaga kesbersihan dan kesehatan tingkungan

b. Pemanfaatan sampah untuk pupuk dan berkebun

c. Pembuatan pupuk organik dari sampah rumah tangga

d. Bertanam secara hidroponik.

2. Pelatihan dan Praktek

Setelah pemaparan materi terkait Pembuatan pupuk organik dan penanaman tanaman dalam pot maupun bertanam secara hidroponik diberikan kepada peserta maka tahap berikutnya adalah pelatihan membuat pupuk organik dari sampah rumah tangga dan bertanam secara hiroponik dengan memanfaatkan botol bekas air minum ukuran 1,5 L (Permadi et al., 2020; Virgota et al., 2019; Solikhah et al., 2018)

3. Pendampingan dan monitoring

Untuk memastikan bahwa program dapat berjalan sesuai dengan yang diharapkan, maka tahapan berikutnya yaitu pendampingan dan monitoring. Pendampingan dan monitoring diladsanakan selama 3 bulan. Tim pengabdian kepada masyarakat mendampingi serta memantau pelaksanaan program melalui video call dan telephone maupun pesan singkat karena dirasa lebih efektif dan efisien serta tidak beresiko tertular Covid-19.

4. Evaluasi

Untuk mengetahui keberhasilan dari kegiatan ini maka evaluasi dilakukan dengan cara sebagai berikut:

a. Kegiatan pemaparan materi dievaluasi berdasarkan partisipasi serta keaktifan peserta.

b. Evaluasi utama atas pengabdian ini adalah apabila target dari program ini tercapai yaitu 
setiap warga memiliki tanaman yang medianya berasal dari sampah yang telah difermentasi atau memiliki tanaman yang ditanam secara hidroponik dirumah masing-masing dengan media dan wadah dari sampah rumah tangga.

\section{HASIL DAN PEMBAHASAN}

\section{Penjajakan Potensi Mitra}

Pandemi Covid-19 memaksa orang tinggal di rumah memunculkan budaya baru, yaitu berkebun di pekarangan rumah berupa sayuran organik. Demikian halnya juga terjadi di kelurahan kestalan kecamatan banjarsari Kota Surakarta. Termasuk daerah yang terdampak pandemi Covid-19 sehingga banyak warganya yang bekerja dari rumah. Hasil observasi tim pengabdian pada masyarakat memperoleh data bahwa kelompak masyarakat yang tergabung dalam kelompok tani "Ngubo Amuktiwo" mempunyai potensi untuk mengembangkan diri menjadi kelompok tani yang handal dan mampu memmanfatkan sampah rumah tangganya untuk bertanam terbukti mereka mempunyai konsep kawasan rumah pangan lestari, yang setiap anggota kelompok sudah memiliki tanaman dalam pot walaupun dengan media tanam dari polybag belum memanfaatkan sampah.

\section{Pemaparan Materi}

Pemaparan materi dan diskusi disampaikan secara daring melalui grup WhatsApp namun sebelumnya materi sudah diberikan dulu baik soft maupun hard copynya. Peserta yang mengikuti paparan dan diskusi sebanyak 25 orang. Dengan demikian semua anggota kelompok mitra mengikuti, ini membuktikan bahwa mitra memiliki kemauan untuk maju dan berkembang yang merupahan modal dasar suatu organisasi. Materi diberikan dalam 2 tahap yang pertama tentang pembuatan pupuk organik padat dan cair sedangkan tahap kedua tentang bertanam secara hidroponik.
Skema pembuatan pupuk organik dan bertanam secara hidroponik digambarkan sebagai berikut:

1. Pembuatan pupuk organik padat dan cair

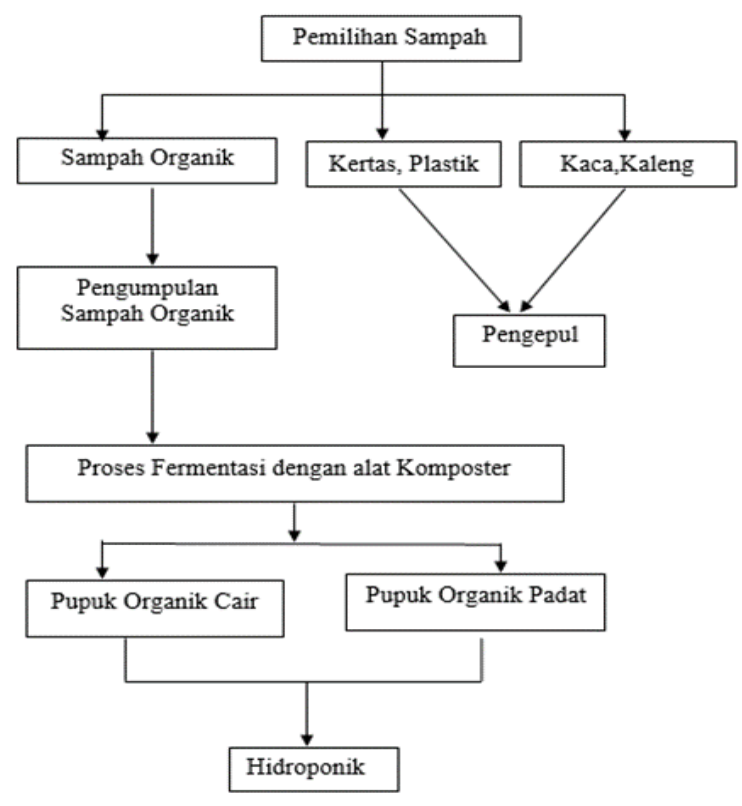

Gambar 1. Skema Pembuatan Pupuk Organik Padat dan Cair

Dari skema pada Gambar 1, dijelaskan bahwa langkah pertama untuk pembuatan pupuk organik padat dan cair yaitu memilah sampah organik dan sampah anorganik. Selanjutnya, sampah organik diproses jadi pupuk sedangkan yang anorganik dijual.

2. Pembuatan wadah hidroponik dari botol bekas minuman

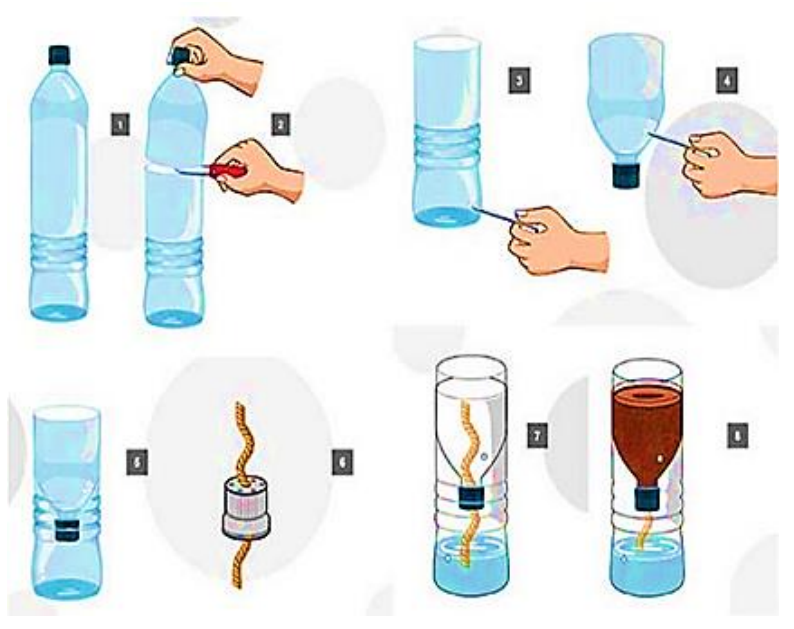

Gambar 2. Pembuatan Wadah Hidroponik Dari Botol Bekas Minuman 
Langkah pembuatan wadah hidroponik dari botol bekas dapat dijelaskan sebagai berikut:

a. Potong botol minuman bekas menjadi dua dengan menggunakan cutter, pisau, atau gunting. Pastikan ukuran botol bagian bawah lebih besar daripada ukuran bagian atas.

b. Lubangi permukaan pada bagian leher botol dengan menggunakan paku kecil di beberapa titik. Lubangi juga bagian penutup botol sebagai jalur masuk sumbu nantinya

c. Masukkan sumbu, kain bekas, atau kain flannel ke dalam celah penutup botol yang akan dibuat. Pastikan sumbu cukup panjang di kedua sisi agar dapat menyerap air yang akan dituangkan dan juga mengenai bagian benih tanaman. Lalu letakkan dengan posisi terbalik ke dalam botol

d. Masukkan pupuk organik padat yang telah dibuat kepotongan yang diatas sebagai media

e. Tuangkan pupuk organik cair ke media hingga batas lobanng ke dalam bagian botol bawah.

f. Masukkan bibit dari pesemaian yang telah dipersiapkan ke dalam media.

g. Pastikan akar bibit terkena dengan bagian sumbu yang sudah basah oleh pupuk

h. Letakkan botol di area yang ramah sinar matahari namun tidak rawan terkena hujan agar benih tumbuh dengan baik.

i. Pantau jangan sampai air dalam botol bagian bawas kering

\section{Pelatihan dan Praktek}

Setelah peserta memahami tentang cara pembuatan opupuk organik padat dan cair serta cara bertanam hidroponik maka kegiatan dilanjutkan dengan pelatihan dan praktek. Dikarenakan masih dalam suasana pandemi Covid-19 maka pendampingan pelatihan dan praktek menggunakan media video yang dikirimkan ke semua peserta.
Proses pembuatan pupuk organik padat dan cair dari sampah rumah tangga dilakukan dengan menggunakan model komposter sebagai berikut:

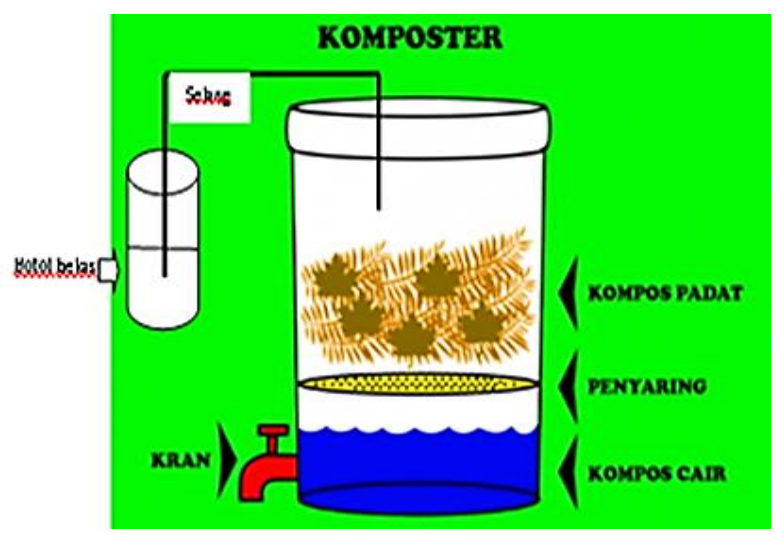

Gambar 3. Model Komposter

Prosedur Kerja :

1. Cincang sampah rumah tangga

2. Masukkan kedalam Komposter

3. Isi komposter dengan air perbandingan 2 bahan 1 air

4. Isi botol bekas minuman dengan air 50\% dan selang plastik dimasukkan

5. Masukkan bio aktifator $\pm 20 \mathrm{ml}$.

6. Tutup rapat-rapat

7. Biarkan selama \pm 21 hari

8. Buka kran dan ambil cairannya (pupuk organik cair)

9. Ambil ampasnya (pupuk organik padat)

10. Ampas padat dipakai sebagai media tanam hidroponik, sedangkan cairannya dipakai sebagai sumber nutrisi.

11. Kegiatan selanjutnya yaitu mempersiapkan wadah untuk hidroponik.

Hasil pantauan tim pengabdian menunjukkan peserta sangat tertarik mencermati video yang tim pengabdian kirim terbukti dari diskusi interaktif lewat grup WhatsApp. Praktek pembuatan pupuk organik padat dan cair membutuhkan waktu selama 3 minggu kemudian dilanjutkan dengan bertanam sayuran hidroponik selama 1,5 bulan yang dimulai dari penyemaian bibit sampai penanaman dan pemanenan. 
Gambar 4 menunjukkan wadah dari potongan bekas air minum yang siap diberi media dan nutrisi.

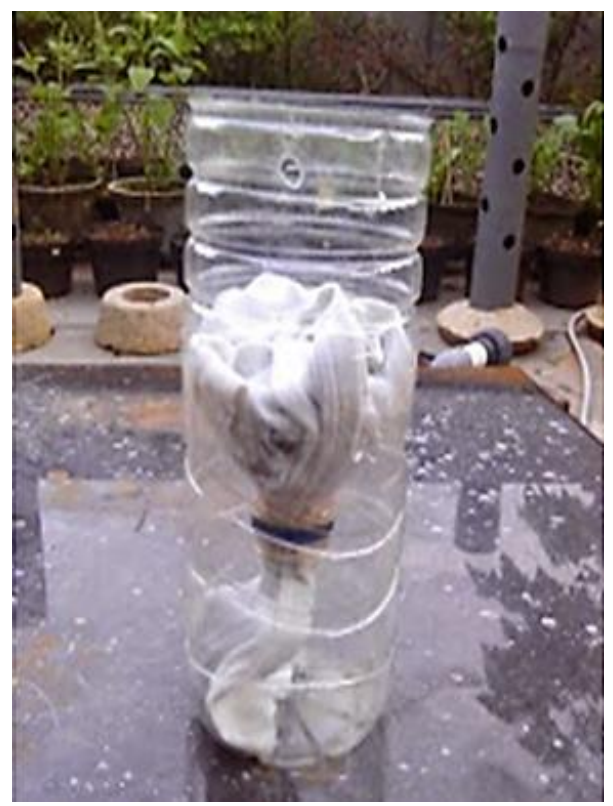

Gambar 4. Wadah Hidroponik

\section{Pendampingan dan monitoring}

Untuk memastikan keberhasilan program maka dilakukan pendampingan dan monitoring. Hasil monitoring menunjukkan bahwa anggota kelompok mitra telah melakukan praktek secara benar. Sebagai contohnya mereka juga menyiapkan penyemaian benih untuk tanaman hidroponik sebagaimana ditunjukkan pada Gambar 5:

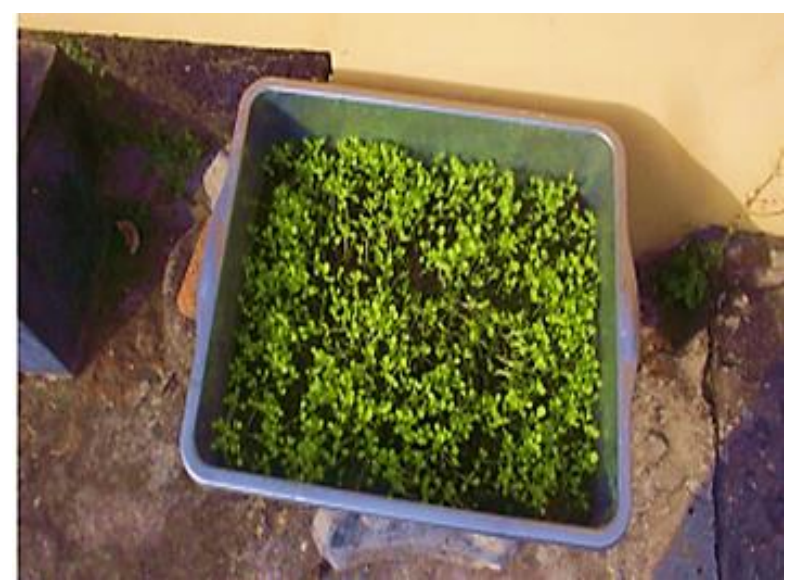

Gambar 5. Persemaian Bibit Selada

Disamping persemaian, terbukti bahwa setiap kelompok mitra telah memiliki tanaman hiroponik minimal 2 tanaman yang bibitnya dari hasilpesemaian sendiri dan medianya dari pupuk organik bahan sampah rumah tangga yang difermentasi dan wadahnya dari botol bekas minum 1,5 L yang dipotong dan diberi sumbu, seperti contoh pada Gambar 6 dan 7:

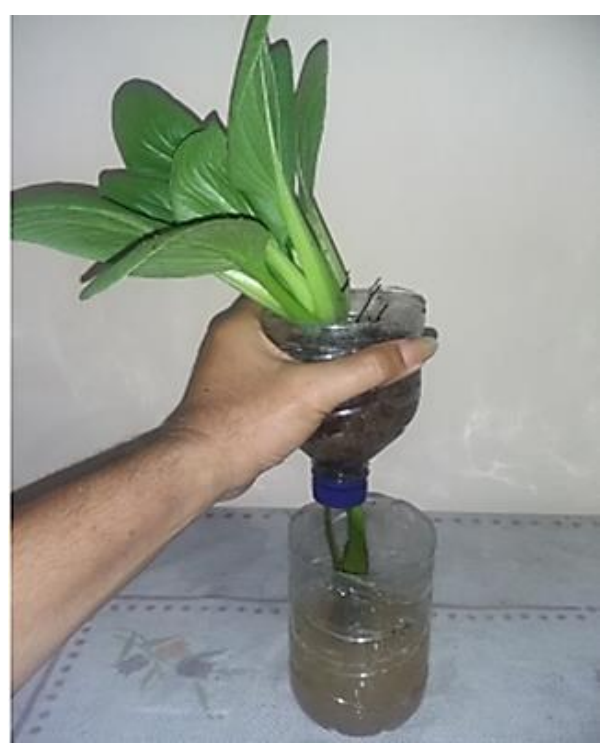

Gambar 6. Hasil Praktek Mitra Dengan Tanaman Sawi Sendok umur 30 hari setelah tanam

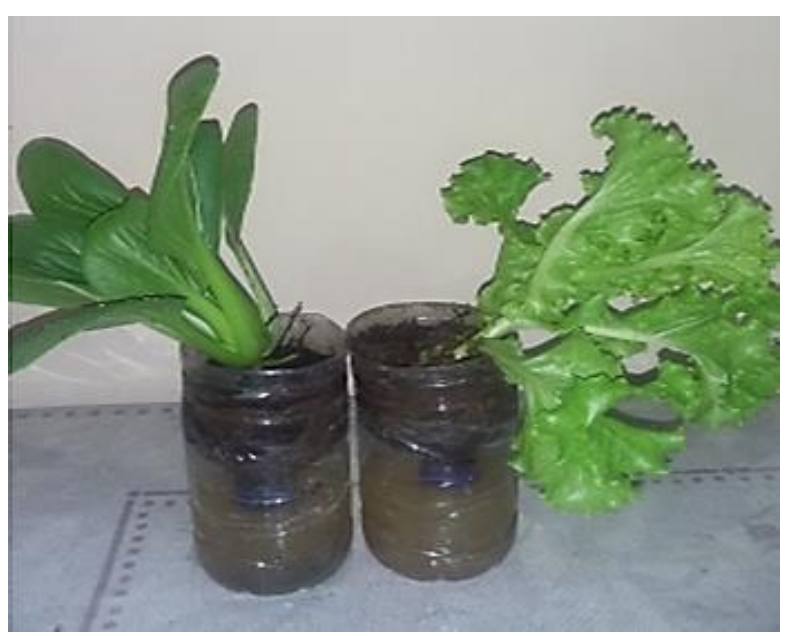

Gambar 7. Hasil Praktek Mitra Dengan Tanaman Sawi dan Selada umur 30 hari setelah tanam

Evaluasi

Berdasarkan evaluasi dari tim pengangabdian terhadap pelaksanaan program bahwa partisipasi masyarakat mitra dalam mengikuti program ini sangat tinggi terbukti dari anggota mitra sebanyak 25 orang selalu hadir dalam setiap pepaparan maupun pada saat latihan dan praktek. Setiap anggota kelompok mitra telah 
mampu mengolah sampah menjadi pupuk organik baik padat dan cair sebagai media tanam hidroponik hal ini ditunjukan dari hasil monitoring tim pengabdian. Kendala yang dihadapi mitra yaitu terbatasnya tatap muka karena masih dalam masa pandemi. Sehingga hasilnya dirasa masih kurang maksimal.

\section{KESIMPULAN}

Pandemi Covid-19 memaksa setiap warga khususnya kelompok mitra beraktifitas di rumah yang mengakibatkan banyak waktu luang yang tersedia, maka berkebun di rumah dengan memanfaatkan sampah rumah tangga sebagai media tanam merupakan solusi paling tepat dikarenakan lingkungan menjadi bersih dan sehat serta hasil panen tanamannya dapat memenuhi kebutuhan sehari hari yang berimbas pada berkurangnya pengeluaran. Disamping itu jika program ini dilaksanakan secara nasional maka tidak mustahil tujuan untuk mewujudkan ketahanan pangan masyarakat Indonesia secara nasional akan tercapai.

\section{REFERENSI}

Ashari, Saptana, Purwantini, T.B. 2012. Potensi Dan Prospek Pemanfaatan Lahan Pekarangan Untuk Mendukung Ketahanan Pangan. Forum Penelitian Agro Ekonomi. 30(1):13-30. http://dx.doi.org/10.21082/fae.v30n1.2012.1 3-30

Cahya, D.L. 2014. Kajian Peran Pertanian Perkotaan Dalam Pembangunan Perkotaan Berkelanjutan (Studi Kasus: Pertanian Tanaman Obat Keluarga Di Kelurahan Slipi, Jakarta Barat). Forum Ilmiah Indonusa. 11(3):324333.

Dwiyanto, B.M. 2011. Model Peningkatan Partisipasi Masyarakat Dan Penguatan Sinergi Dalam Pengelolaan Sampah Perkotaan. Jurnal Ekonomi Pembangunan: Kajian Masalah Ekonomi dan Pembangunan. 12(2):239-256. https://doi.org/10.23917/jep.v12i2.196
Lantarsih, R., Widodo, S., Darwanto, D.H., Lestari, S.B., Paramita, S. 2011. Sistem Ketahanan Pangan Nasional: Kontribusi Ketersediaan Dan Konsumsi Energi Serta Optimalisasi Distribusi Beras. Analisis Kebijakan Pertanian. 9(1):33-51. http:/ /dx.doi.org/10.21082/akp.v9n1.2011.33 $-51$

Permadi, H., Yuliana, Wardhani, I.S., Nastiti, N.D., Prasetyo, S.M. 2020. Workshop Pembuatan Hidroponik Wick System Sebagai Upaya Ketahanan Pangan Masyarakat Desa Kasri. Jurnal Graha Pengabdian. 2(3):202-211.

Rosnawati, W.O., Bahtiar, Ahmad, H. 2017. Pengelolaan Sampah Rumah Tangga Masyarakat Pemukiman Atas Laut Di Kecamatan Kota Ternate. Techno: Jurnal Penelitian. 6(2):45-53. http://dx.doi.org/10.33387/tk.v6i02.569

Solikhah, B., Suryarini, T., Wahyudin, A. 2018. Pemberdayaan Ibu Rumah Tangga Melalui Pelatihan Hidroponik. Jurnal Abdimas. 22(2):121-127.

Suryani, A.S. 2020. Dampak Pandemi Covid-19 Terhadap Lingkungan Global. Info Singkat: Pusat Pengkajian Pengolahan Data dan Informasi. 12(13):13-18.

Syahputra, R. 2020. Upaya Pemanfaatan Halaman Rumah Sebagai Lahan Pertanian Tanaman Budidaya Untuk Kebutuhan Konsumsi Dan Pemasaran Masyarakat Pada Masa Covid 19 Di Kelurahan Tempuling. Jurnal Agro Indragiri. 6(2):30-41. https://doi.org/10.32520/jai.v6i2.1470

Virgota, A., Farista, B., Candri, D.A., Ahyadi, H., Jupri, A. 2019. Peningkatan Kapasitas Masyarakat dalam Pengolahan Sampah Sebagai Kompos di Kelurahan Dasan Geres Lombok Timur. Jurnal Pengabdian Magister Pendidikan IPA. 2(2):143-147. https://doi.org/10.29303/jpmpi.v2i2.376

Wulandani, B.R.D., Anggraini, W. 2020. Food Estate Sebagai Ketahanan Pangan Di Tengah Pandemi Covid-19 Di Desa Wanasaba. Selaparang: Jurnal Pengabdian Masyarakat Berkemajuan. $\quad$ 4(1):386-390. https://doi.org/10.31764/jpmb.v4i1.3062 